\title{
The Effect of Operating Cash Flow on the Profit Growth
}

\author{
Agus Widarsono, Mega Rahmawati \\ Universitas Pendidikan Indonesia \\ agus.widarsono@upi.edu
}

\begin{abstract}
This study aims to investigate the effect of operating cash flow to the profit growth. This study employs associative approach. The objective of the study is to obtain the picture concerning operating cash flow, and to depict the mechanism regarding profit growth in State-Owned Enterprise (SOE) bank, and also to reveal the effect of operating cash flow to the profit growth. The sampling is carried out by non-probability sampling through purposive sampling approach with several criteria (1) Bank; (2) State-owned bank which are listed in BEI; (3) Bank which publish cash report within eight years in a row from 2007-2014. Four State-Owned Enterprises (SOE) bank in Indonesia are involved within 2007-2014 period as the sample of the study. The data are analyzed through sample linear regression test. Analyses show that operating cash flow positively affect to the profit growth. The effect of operating cash flow variable $(X)$ to the profit growth $(Y)$ is gained $R$ value 0.165 or $16.5 \%$ which is elaborated by operating cash flowvariable $(\mathrm{X})$ and the rest is $83.5 \%$ is explained by another variable.
\end{abstract}

Keywords-operating cash flow; profit growth; operating cash; earnings

\section{INTRODUCTION}

Public bank is one of the institutions that has an important role inside the circumstance of economic activity, trade because through credit activity and several efforts given by the bank, it could serve both economic and trade requirements. It can also be inferred that public bank is a core system of the country. . Bank is considered as a safe financial institution for undertaking various financial activities, that is fund savings activities, investment, remittances from one place to another quickly and safely, as well as other financial activities. Besides, the bank is as an institution that acts as a financial intermediary parties that have excess funds with the parties that need funding, as well as an institution functioning expedite payment traffic.

Bank has operations as well as other companies. The fund to cover the operation can be obtain from any sources, for example it can be obtained from the bank itself, society, and another institution. SOE definition according to Law No. 19 of 2003 is a business entity of all or a large part of its capital owned by the State through the requirement that is directly derived from the State assets that are separated. State-owned banks consisting of Bank BNI, Bank BRI, Bank Mandiri and Bank BTN have substantial profits compared to private banks. Seen in the Fig. 1 shows the value of earnings in state-owned banks and private banks 2012-2014. It also becomes a standard of the bank whether it is capable to cover the operation from that source or not. BRI bank shows the highest income compared to another.

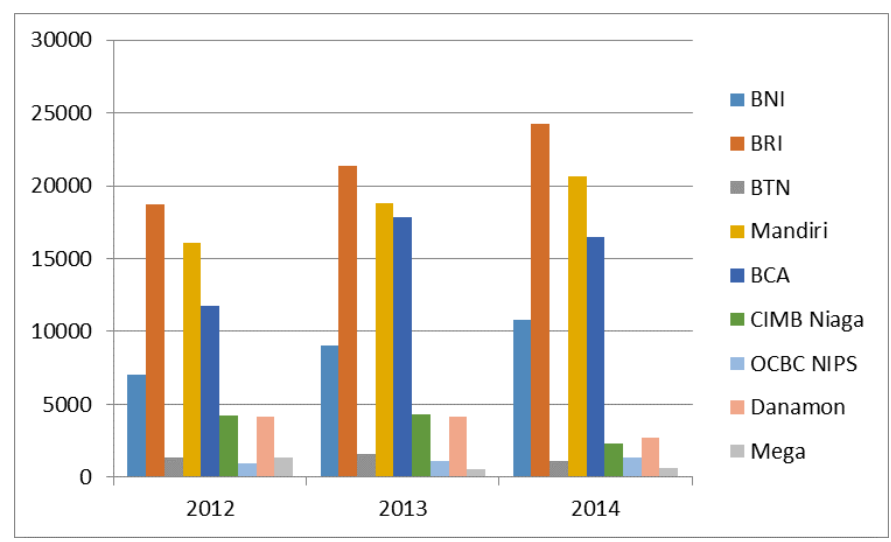

Fig. 1. SOE Bank and Private Bank Profit

Fig. 1 shows that the profit of state-owned banks earn the highest profit as the Bank BRI and Bank Mandiri. Based on the record Bisnis.com, PT Bank Rakyat Indonesia Tbk gets the largest profit among the other three state-owned banks. Profits of BRI last year reached Rp24.2 trillion or grew by $13.5 \%$ from the year 2013 were valued at $\mathrm{Rp} 21.3$ trillion $^{[1]}$.

Based on the above news, therefore, the research puts an emphasis to analyze net income of the State-Owned Enterprise bank. This is because State-Owned Enterprise bank consistently holds the net income which tends to keep increasing. One of the crucial information to assess a company is through a financial statement. Financial statement aims to facilitate information concerning financial condition, efforts and operating cash flow which is very fundamental for almost the statement users to make economic policies. The objective of the study is to obtain the picture concerning operating cash flow, and to depict the mechanism regarding profit growth in State-Owned Enterprise (SOE) bank, and also to reveal the effect of operating cash flow to the profit growth.

Inside the circumstance of financial statement of several banks in Indonesia, namely BNI, BRI, BTN, and Mandiri, it can be inferred that operating cash flow of State-Owned Enterprise (SOE) is generally in a good condition. It can be indicated from the shape of the net income which is identified that operating cash flow lies in positive value. It can also be stated that State-Owned Enterprise (SOE) bank obtained income in eight periods. Although, in fact, it is said that operating cash flow which is used in operation lies in negative 
value. This phenomenon happened in two banks, namely BNI and BTN at the end of the period in 2014. Based on the financial statements of each of the state-owned bank in the 2007-2014 period reported that operating cash flow was fluctuated. Operating cash flow is shown in Bank BNI in 2008 decreased by $\mathrm{Rp}$ (12 340) billion, rose again in 2009 to $\mathrm{Rp}$ 4697 billion, but fell back in the year 2010 amounted to Rp (14 173) billion and in the year 2011 increased back. The year 2012 has decreased back but the decline this year is not negative. Then in 2013 and 2014 decreased negative. In contrast, Bank Mandiri decreased in 2008 and in 2009 to 2011 had increased continuously. In the year 2012 has decreased and 2013 to 2014 had increased.

Based on the financial statements of each of the stateowned bank reported profit growth in the 2007-2014 period fluctuated. Profit growth, strong profit growth normally steady means that the profit growth is good, while the facts in the graph fluctuates. Profit growth at Bank BTN from the years 2007-2009 has increased, but in the year 2010 has decreased and in 2011-2013 increased whereas in 2014 fell back. Profit growth at Bank BTN is stable but when compared with other state-owned banks, only Bank BTN profit growth is slowing. The greater the profits of a company, the greater the presumption that the company has gained success in running the operations of the company ${ }^{[2]}$.

Operational costs are costs arising from the operations of the company. They have the results of the operational costs affect profit growth ${ }^{[3]}$. Operational costs will indirectly affect operating cash flow, because operating costs would reduce the influx of cash operating expenses. It means, indirectly, the study said that operating cash flows have an impact on profit growth. PT Indofood Sukses Makmur Tbk stated that operating cash flow have a significant effect on net income, while PT Unilever Indonesia Tbk stated that operating cash flow is not significant effect on net income ${ }^{[2]}$. Total Asset Turnover (TATO) and Net Profit Margin (NPM) has a significant influence on the growth of earnings ${ }^{[4]}$. Current ratio, total asset turnover, invetory turnover, net profit margin and return on assets did not significantly affect earnings growth ${ }^{[5]}$.

\section{LITERATURE REVIEW}

Every running enterprise requires income which can be obtained from cash income or revenue. That cash is very important as a concept of fund ${ }^{[6]}$. The investors' decision, creditor, and others put an emphasis on the future assessment of cash flow statement. It can be used every time as trade tools when necessary. Operating cash flow is a principal revenue producing activities and another activity which is not categorized as investment activity and funding activity ${ }^{[7]}$.

Cash inflow refers to the income for company or bank or even institution. Meanwhile, cash out flow stands for the outcome to pay or cover, for example paying salary for employee etc. Therefore, cash flow statement, in general, comes from a transaction or another phenomenon which affects the value of income statement.

Growth ratio is a measurement to investigate the capability of the company to entirely place itself inside the circumstance of economic system, or economic system for identical industry, this ratio is determined by dividing the amount of the years with the amount of the basic years where the basic years are classified as $100 \%{ }^{[8]}$. This ratio indicates the capability of the company in increasing the net income compared to recent year $^{[9]}$. In line with the explanation aforementioned, it can be stated that the profit growth stands for the rising net income percentage which is obtained by the company. A good profit growth is a fundamental requirement in every institution to run well.

Everything built to have objectives, it also refers to the company or bank which also have concrete objectives. One of the objectives is to gain profit or income. Therefore, both bank and company are commonly oriented to gain profit or income. It can be inferred that every single company should optimize any profits. That the last number in a report is net profit. The profit, in this study, surely refers to the net profit ${ }^{[10]}$. The company always have an expectation in possessing abundant profit. From year to year, both cash inflow and cash out flow are inevitably to happen. It would be better if the company figures out how to keep the profits increasing.

The growth ratio is a tool to measure how capable the company in competing with another company in same industrial area really is. The bigger the profits collected by the company, the bigger the chance for the company to successfully run operational activities ${ }^{[2]}$.

Operational fund refers to the fund that appears right from the operational activity of the company. Possessing the result of operational fund will potentially affect the profit growth ${ }^{3}$. Operational fund will indirectly give an effect to operating cash flow, because this operational fund will reduce income from the cash out flow operation. Based on the previous explanation, this study implicitly infers that operating cash flow affects to the profit growth. Operating cash flow and cash flow of funding has a significant positive relationship ${ }^{[11]}$.

Operating cash flow is the bigger picture of operation activity compared to the net profit. It covers entire activity which is related with profit or revenue. The measurement does not only cover income and outcome, but also the existence of cash flow statement. Operating cash flow is frequently related with net profit to assess the quality assurance. Some report users claim that operating cash flow will reflect the better profit quality. Operating cash flow becomes an effective tester to the net profit, however it surely is not a substitution of the net profit itself ${ }^{[12]}$. Current ratio, debt to equity ratio, total asset turnover and inventory turnover significant effect on earnings growth $^{[13]}$. Debt to total capital assets significant effect on earnings growth ${ }^{[14]}$.

\section{RESEARCH METHODS}

The study is characterized as a quantitative study since it employs associative approach to analyze the data. Since it is expected to describe the variables and to determine the effect of operating cash flow to profit growth. The data used in this research is secondary data in the form of financial statements. The object of this research is the operating cash flow and profit growth. The population is a state-owned bank to go public in Indonesia listed on the Indonesia Stock Exchange (BEI). The sampling technique using a non-probability sampling with 
purposive sampling approach with criteria (1) Bank; (2) government-owned banks listed on the Stock Exchange; (3) banks that publish their financial statements for eight consecutive years from 2007 to 2014 year. The sample consists of four state-owned bank listed in Indonesia in the 2007-2014 period a total of four state-owned bank.

\section{FINDINGS AND DISCUSSION}

\section{A. Describe Operating Cash Flow}

Operating cash flow is a broader outlook on operating activities compared to net income. Cash flows from operations include all activities related to the company's earnings. Operating Cash Flow ratio in this study was calculated by the amount of operating cash flow divided by current liabilities.

Cash flows from operating activities report cash receipts and payments relating to the company's operations. The net cash flow from operating activities is usually different from the amount of net income for the period. This difference occurs because the revenues and expenses are not always received or paid in cash. Operating cash flow shows the company's main revenue-producing activity. In addition, besides to show the company's main activity, also show the limits of cash generated from operations to pay off loans, pay dividends, make investments and maintain the operational capabilities of the entity without obtaining any funding from external sources.

In the financial statements of each banks shows that the value of the operating cash flow there is negative and positive. Based on the financial report on each bank of negative operating cash flow resulting from the investment bank and use part of the loan drawdown of capital to finance the operations, bank operations and investment activities are partly financed with loan funds. While the positive operating cash flow due to the cash proceeds greater than cash expenditures, banks use cash from operations to repay debt.

$$
\text { Operating cash flow ratio }=\frac{\text { Operating cash flow }}{\text { Current liabilities }}
$$

Formula 1. Operating cash flow ratio

The ratio of operating cash flow is obtained from operating cash flow divided by current liabilities. Current liabilities means debts that must be paid or pay off within a year. Operating cash flow ratio calculating operating cash flow ability to pay current liabilities, this ratio is obtained by dividing the operating cash flow by current liabilities ${ }^{[15]}$.

The average description ratio of operating cash flowfrom State-Owned Enterprise Bank, it is identified that Mandiri bank has the highest operating cash flowwith 26.88. Meanwhile, the lowest average description of operating cash flowappears in BNI bank with 11.65. It also means that Mandiri, which is identified as the highest operating cash flowwith 26.88 , every single a hundred rupiah of current liabilities is guaranteed by eighty eight rupiah of cash flow statement. That ratio indicates that operating cash flowis above one which also means there is a possibility for the company to pay current liabilities without using operating cash flowfrom another activity.
It is different with BNI from the result aforementioned that operating cash flowratio lies in -11.65 which means that for every single a hundred rupiah of current liabilities is guaranteed by sixty five rupiah of cash flow statement. That ratio shows that operating cash flowis below one which also means that there is a posibility that company is not able to pay current liabilities without using cash flow statement. Inside the company, normal activity is a main activity which is run every time. The lack of generating cash flow from main activity to pay an obligation from normal activity can potentially affect the company bankrupt.

\section{B. Describe Profit Growth Ratio}

Any company or bank or institution that has been running it will generate a profit can be referred to as the profits, if revenue is greater than the load. From year to year will definitely be an increase or decrease of the profit. And it is better when profit is always increasing. Profit is the difference of income to expenses at a certain time. Measurement of profit is not only important to determine the company's achievements but also important as the information for determining the distribution of income and investment policies. It is because the biggest trouble of the company bankrupt is the incapability to pay short term liabilities.

Increase in Net Income $=\frac{\text { Net Profit This Year - Net Profit Last Year }}{\text { Net Profit LastYear }}$

Formula 2. Increase in net income

Reducing profit current period with prior periods and then dividing the profit the previous period ${ }^{[9]}$. The average description of profit growth lies in 0,2706448 can be fixed into 0.27 which means the profit obtained by bank in period has increased $27 \%$ compared to previous period.

\section{The Effect of Operating Cash Flow to The Profit Growth}

Statistical test through the use of the model of P-Plot diagram indicates the data which spreads around diagonal line and follows the direction of the diagonal line itself. Therefore, it can be stated that the data fulfill the test of normality or the data are normally distributed. In order to strengthen the result, non-parametric test is initiated (One-Sample KolmogrovSmirnov Test). It shows that variable has value of significance 0.200 which also means that its significance value is above 0.05 .

The result of linearity test lies in 0.021 . The value of ssignificance is smaller from 0.06 which also means there is a linear correlation between operating cash flow $(\mathrm{X})$ with profit growth variable $(\mathrm{Y})$.

Regression formula is formulated as follow: $\mathrm{Y}=-1.1613+$ $0.205 \mathrm{X}$. According to the formula of regression, it can be inferred that operating cash flow has a positive correlation. In other words, $\mathrm{H} 0$ is rejected and $\mathrm{Ha}$ is accepted. It is also indicated with sig coefficient in the table with 0.021 and value of significance 0.05 . Knowing that the value of sig is smaller from the significance, so it can be inferred that the hypothesis (H0) is rejected. In other words, operating cash flow positively affects the growth income of State-Owned Enterprise Bank. The effect of operating cash flow variable (X) to the profit 
growth ( $\mathrm{Y}$ ) is gained $\mathrm{R}$ value 0.165 or $16.5 \%$ which is elaborated by operating cash flow variable $(\mathrm{X})$ and the rest is $83.5 \%$ is explained by another variable.

Operating cash flow is a bigger picture of operational activity compared to the net profit. It covers entire company activity which is related with profit or revenue. This measurement does not only cover income and outcome, but also it does delineate cash operational activity, operating cash flow is commonly related net profit to assess its quality. Some report users claim that operating cash flow ratio will reflect the better quality of the profit. Operating cash flow becomes a concrete tester for net profit, however it is not a substitution of net profit ${ }^{[12]}$.

\section{CONClusion And SugGestions}

Operating cash flow ratio indicates that every single a hundred rupiah of current liabilities is guaranteed by sixty seven rupiah of cash flow statement. The aforementioned ratio shows that operating cash flow is above one which means there is a possibility that State-Owned Enterprise Bank is able to pay current liabilities, without using cash from other activities. Besides, the profit growth ratio which is gained by StateOwned Enterprise Bank in period is significantly increasing $27 \%$ compared to the previous period.

The present study has several limitations. This study only uses operating cash flow variable. Therefore, it is suggested for the next research to conduct a research with more variables or other variables. Besides, it is also suggested for further research to conduct the sample of the study in larger area with different characteristics. The result of the study is expected to give contributions as considerations for policy makers concerning the initiation of operating cash flow and profit growth.

\section{REFERENCES}

[1] Petriella Y. (2015, 1 Maret). Kinerja bank BUMN kinclong pada 2014, kecuali BTN ini ulasannya. Diakses dari http://finansial.bisnis.com/read/20150301/90/407562/kinerja-bank-bumnkinclong-pada-2014-kecuali-btn.-ini-ulasannya.

[2] Sutarti, Sulaeman A. Pengaruh Arus Kas Operasi Terhadap Pertumbuhan Laba Perusahaan. Jurnal Ilmiah Ranggagading. 2011 Oktober; 11(2): 125A-117A.

[3] Setiawan S, Winarsih. Faktor-faktor yang Mempengaruhi Pertumbuhan Laba Bank Syariah di Indonesia. Jurnal Ekonomi Manajemen Akuntansi. 2011 Oktober; 19(31):1A-17A.

[4] Hamidu NP. Pengaruh Kinerja Keuangan Terhadap Pertumbuhan Laba Pada Perbankan di BEI. Jurnal Riset Ekonomi Manajemen, Bisnis dan Akuntansi. 2013 Juni;1(3):711A-721A.

[5] Rizkiyah. E. (2010). Faktor-faktor yang Mempengaruhi Pertumbuhan Laba pada Perusahaan Otomotif yang Go Public di Bursa Efek Indonesia. Universitas Pembanguan Nasional Veteran. 2010.

[6] Prastowo D. Analisis Laporan Keuangan Konsep dan Aplikasi. Yogyakarta: Unit Penerbit dan Percetakan. 2015. 34.

[7] Ankarath N, Mehta K J, et al. Memahami IFRS Standar Pelaporan Keuangan Internasional. Jakarta Barat: PT INDEKS. 2012. 43.

[8] Kasmir. Analisis Laporan Keuangan. Jakarta: PT Raja Grafindo Persada. 2011. 114.

[9] Harahap SS. Analisis Kritis Atas Laporan Keuangan. Jakarta: PT Raja Grafindo Persada. 2015. 310.
[10] Soemarso SR. Akuntansi Suatu Pengantar. Jakarta: Salemba Empat. 2014. 227.

[11] Frank BP, James OK. Cash flow and corporate performance: a study of selected food and beverages companies in nigeria. European Journal of Accounting Auditing and Finance Research. 2014 September. 2(7). 7787.

[12]Subramanyam KR., Wild JJ. Analisis Laporan Keuangan. Jakarta: Salemba Empat. 2012. 15A-17A.

[13] Sinaga R. Analisis Rasio Keuangan Dalam Memprediksi Pertumbuhan Laba Pada Perusahaan Property dan Real Estate yang Terdaftar di BEI Tahun 2006-2008. Universitas Sumatera Utara. 2010.

[14] Alfanadiah M. Analisis Prediksi Pertumbuhan Laba pada Perusahaan Manufaktur Subsektor Tekstil dan Garment Go Public. Universitas Jember. 2013.

[15] Harrison WT., Hongren CT, et al. Akuntansi Keuangan. Jakarta: PT Gelora Aksara Pratama. 2011. 268. 